\title{
Strategy of Water Pollution Control Base On Social Economic Activitiy, in Karang Mumus River, Samarinda East Kalimantan, Indonesia
}

\author{
Vita Pramaningsih ${ }^{1 *}$, Slamet Suprayogi ${ }^{2}$, and Setyawan Purnama ${ }^{2}$ \\ ${ }^{1}$ Doctoral Program of Environmental Science, School of Postgraduate Studies, Gadjah Mada University, Yogyakarta - Indonesia \\ (Department of Environmental Health, Univers itas Muhammadiyah Kalimantan Timur, East Kalimantan - Indonesia) \\ ${ }^{2}$ Department of Environmental Geography, Faculty of Geography, Gadjah Mada University, Yogyakarta - Indonesia
}

\begin{abstract}
Water Pollution in Karang Mumus River caused society behavior along the river. Daily activity such as bath, washing and defecate at the river. Garbage, sediment, domestic waste and flood are river problems should be solved. Purpose this research is make strategy of water pollution control in the Karang Mumus River. Method used observation in the field, interview to the society, industry, public activity along the river and government of environment department. Further create data using tool of Analys is Hierarchy Process (AHP) to get the strategy to control water pollution in the river. Actors have contribute pollution control are government, industry and society. Criteria to pollution control are society participation, low, human resources and sustainable. Alternative of pollution control are unit garbage storage; lic ense loyalty for industry and waste; communal waste water installation; monitoring of water quality. Result for actor priority are government (0.4); Industry (0.4); Society $(0.2)$. Result for priority criteria are society participation (0.338), low (0.288), human resources (0.205) and sustainable (0.169). Result for priority alternative are unit garbage storage (0.433); license loyalty for industry and waste $(0.238)$; communal waste water installation (0.169); monitoring of water quality $(0.161)$.
\end{abstract}

\section{Introduction}

Water pollution in Karang Mumus River is worse caused social economic activity along the river. There are communities in flood plain area had done daily activity such as bath, washing and defecate in the river. Garbage, domestic waste and flood are problems in Karang Mumus River should be solved.

Water Quality in Karang Mumus River has polluted base on Government of Environment Department at Samarinda around 2009 until 2012 [1]. Report from Government of Environment Department during 2010 2015 found Biological Oxygen Demand (BOD), Chemical Oxygen Demand (COD) and Fecal Colliform along the Karang Mumus River already out of standard base on Government Regulation in East Kalimantan No. 2 / 2011 about Management of Water Pollution. Upstream to downstream land use are residence; city, market, a lot of residences in flood plain area have not relocated; market, a lot of residences in flood plain area have been relocated and port in the estuary [2]. Land use a long the Karang Mumus River shown in Figure 1.

Society has not awareness to keep the river. Society behaviour trough waste and defecate in the river make polluted. It's happen because of there are not enough garbage storage in the community. Then nothing communal waste water installation to manage domestic waste. Community in the flood plain area know that water quality of the river is poor but still use it for daily activity such as bath, washing and defecate [3].

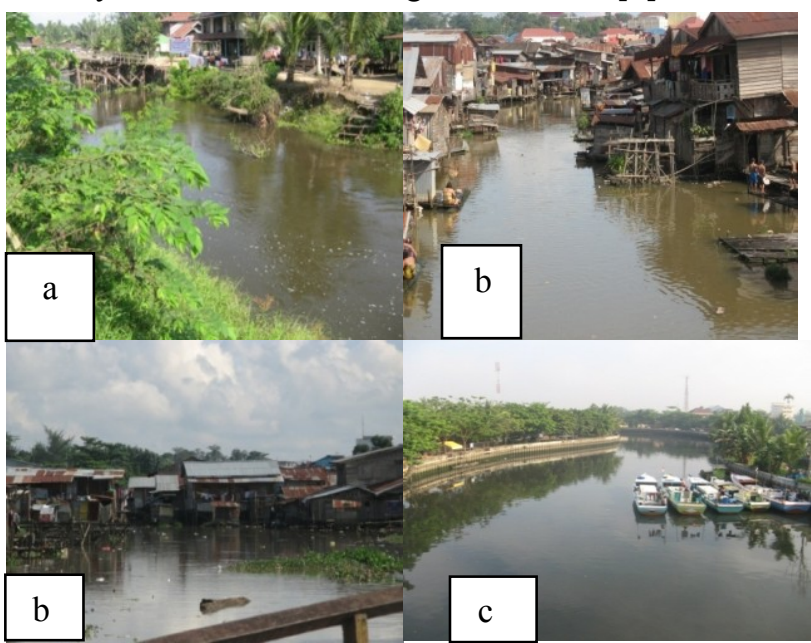

Fig. 1. (a). Head water with vegetation; (b) centre segment with a lot of community in the flood plain; (c) down stream with relocation of flood plain.

Measurement 2016 of Biological Oxygen Demand (BOD) in Karang Mumus has been polluted, shown in Table 1. The result compared with East Kalimantan Provice Regulation No. 2 / 2011 about Water Quality Management and Water Pollution Control. 
Table 1. Pollution of BOD along Karang Mumus River

\begin{tabular}{|c|c|c|c|c|}
\hline No. & Location & Code & $\begin{array}{l}\text { BOD } \\
(\mathrm{mg} / \mathrm{L})\end{array}$ & $\begin{array}{c}\text { BOD } \\
\text { Standard } \\
(\mathrm{mg} / \mathrm{L}) \\
\end{array}$ \\
\hline 1 & $\begin{array}{l}\text { Waduk Benanga } \\
\text { Bridge }\end{array}$ & Al & 17,1 & 3 \\
\hline 2 & Lempake Jaya River & B2 & 17,1 & 3 \\
\hline 3 & Bengkuring River & B3 & 38 & 3 \\
\hline 4 & $\begin{array}{l}\text { Tepian Lempake } \\
\text { Bridge }\end{array}$ & A2 & 20,9 & 3 \\
\hline 5 & $\begin{array}{l}\text { Mugirejo-Gn. Lingai } \\
\text { River }\end{array}$ & B4 & 7,6 & 3 \\
\hline 6 & $\begin{array}{l}\text { Gunung Lingai (Jl. } \\
\text { P.M. Noor) Bridge }\end{array}$ & $\mathrm{A} 3$ & 13,95 & 3 \\
\hline 7 & Sempaja River & B5 & 16,2 & 3 \\
\hline 8 & $\begin{array}{l}\text { Drainage A.Yani } \\
\text { (Gelatik-Pemuda) }\end{array}$ & B6 & 15,2 & 3 \\
\hline 9 & $\begin{array}{l}\text { Pramuka-UNMUL } \\
\text { River }\end{array}$ & B7 & 9,5 & 3 \\
\hline 10 & Gelatik Bridge & A4 & 9,5 & 3 \\
\hline 11 & $\begin{array}{l}\text { Drainage } \\
\text { Lembuswana-Vorvoo }\end{array}$ & B8 & 23,4 & 3 \\
\hline 12 & S. Parman Bridge & A5 & 12,55 & 3 \\
\hline 13 & Perniagaan Bridge & A6 & 10,8 & 3 \\
\hline 14 & $\begin{array}{l}\text { Drainage Jl. Gatot } \\
\text { Subroto }\end{array}$ & B9 & 22,8 & 3 \\
\hline 15 & $\begin{array}{l}\text { Drainage Jl. Lambung } \\
\text { Mangkurat }\end{array}$ & B10 & 39,9 & 3 \\
\hline 16 & $\begin{array}{l}\text { Drainage P. } \\
\text { Hidayatullah }\end{array}$ & B11 & 12,6 & 3 \\
\hline 17 & Sei Dama Bridge & A7 & 9 & 3 \\
\hline
\end{tabular}

Base on those problems needed strategy to control water pollution in the river. It shown society behaviour, government low and instrument to waste management. Analysis Hierarchy Process (AHP) used for choose the alternative as strategy to control water pollution in the river. AHP is a theory of measurement through pair wise comparisons and relies on the judgment of experts to derive priority scales [4]. AHP as comprehensive safety evaluation method combining qualitative and quantitative analysis, has been used in many fields of safety and environmental science [5]. Main idea of AHP is to judge the important level between pair wise indicators by the separation of a complex problem into several hierarchies and several factor, that is, to construct a judgment matrix and determine the maximum eigen value of this matrix and its eigenvector by calculation, which could yield the weights of important level of different plans and provide the basis for the best plan [6].

The fundamental scale of absolute number to construct pair wise comparison matrices use the priorities obtained, shown in Table 2. Expert respondents (actor) are government, industry and communities along the Karang Mumus River. Respondents are choose the people lives and known the environment, condition, human activity along Karang Mumus River. Criteria in the hierarchy matrix to make pollution control strategy are sustainable development, communities participation, human resources and low regulation. Criteria is point of think to chose alternative. Then Alternative in the hierarchy matrix had chosen are industry and waste management license, water quality monitoring, waste water treatment monitoring and garbage storage unit. Priority alternative of pollution control in Cibanten River, Banten, Indonesia was water quality monitoring, city spatial layout review, low regulation, stakeholder, socialization and waste water treatment communal [7].

Table 2. Scale of Absolute Number in AHP

\begin{tabular}{cll}
\hline $\begin{array}{c}\text { Intensity of } \\
\text { Importance }\end{array}$ & \multicolumn{1}{c}{ Definition } & \multicolumn{1}{c}{ Explanation } \\
\hline 1 & Equal importance & $\begin{array}{l}\text { Two activities } \\
\text { contribute equal to } \\
\text { the objective slightly }\end{array}$ \\
3 & Moderate importance & $\begin{array}{l}\text { Judgement } \\
\text { favour one activity } \\
\text { over another } \\
\text { Judgement strongly } \\
\text { favour one activity } \\
\text { over another } \\
\text { An activity is } \\
\text { favoured strong importance } \\
\text { strongly over another } \\
\text { An activity with the } \\
\text { highest possible } \\
\text { order of affirmation }\end{array}$ \\
\hline
\end{tabular}

\section{Materials and Methods}

The map of sampling location along Karang Mumus River, shown in Figure 2.

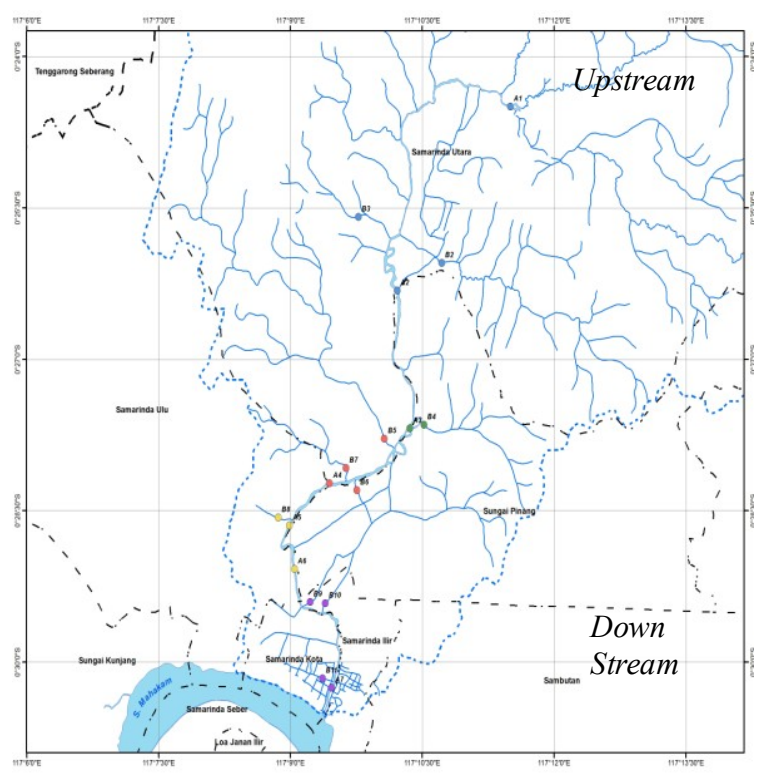

Fig. 2. Sampling Location Spot

Each respondent provided judgement to estimate the dominance factor to get strategy water pollution control follow as the hierarchy matrix. Judgement base on pairwise comparison using scale. Analysis strategy to control water pollution in the Karang Mumus River, used AHP to establish a hierarchical model/matrix with three layers included, shown in Figure 3. Actors judgement have analysed by expert choice 11 tools to get priority value. 


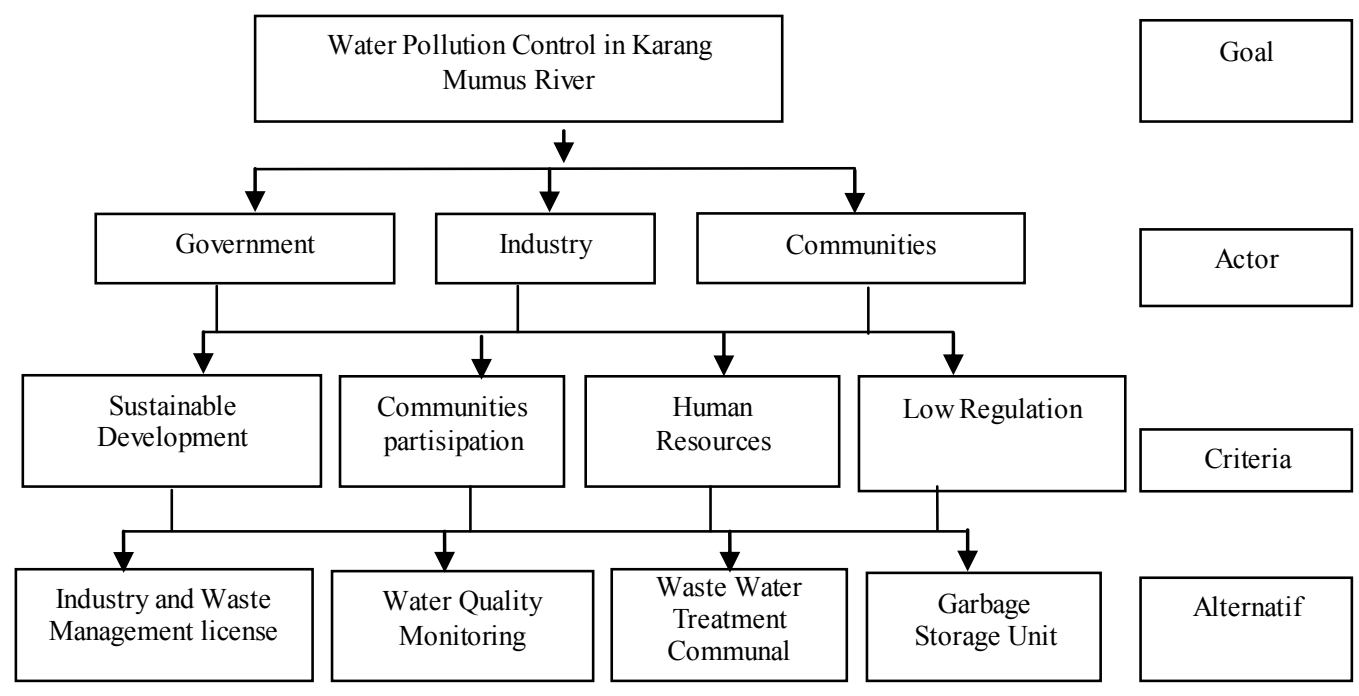

Fig. 3. Hierarchical Matrix

\section{Results and Discussion}

Result of expert choice to analysed alternative of pollution control strategy, shown in Figure 4.

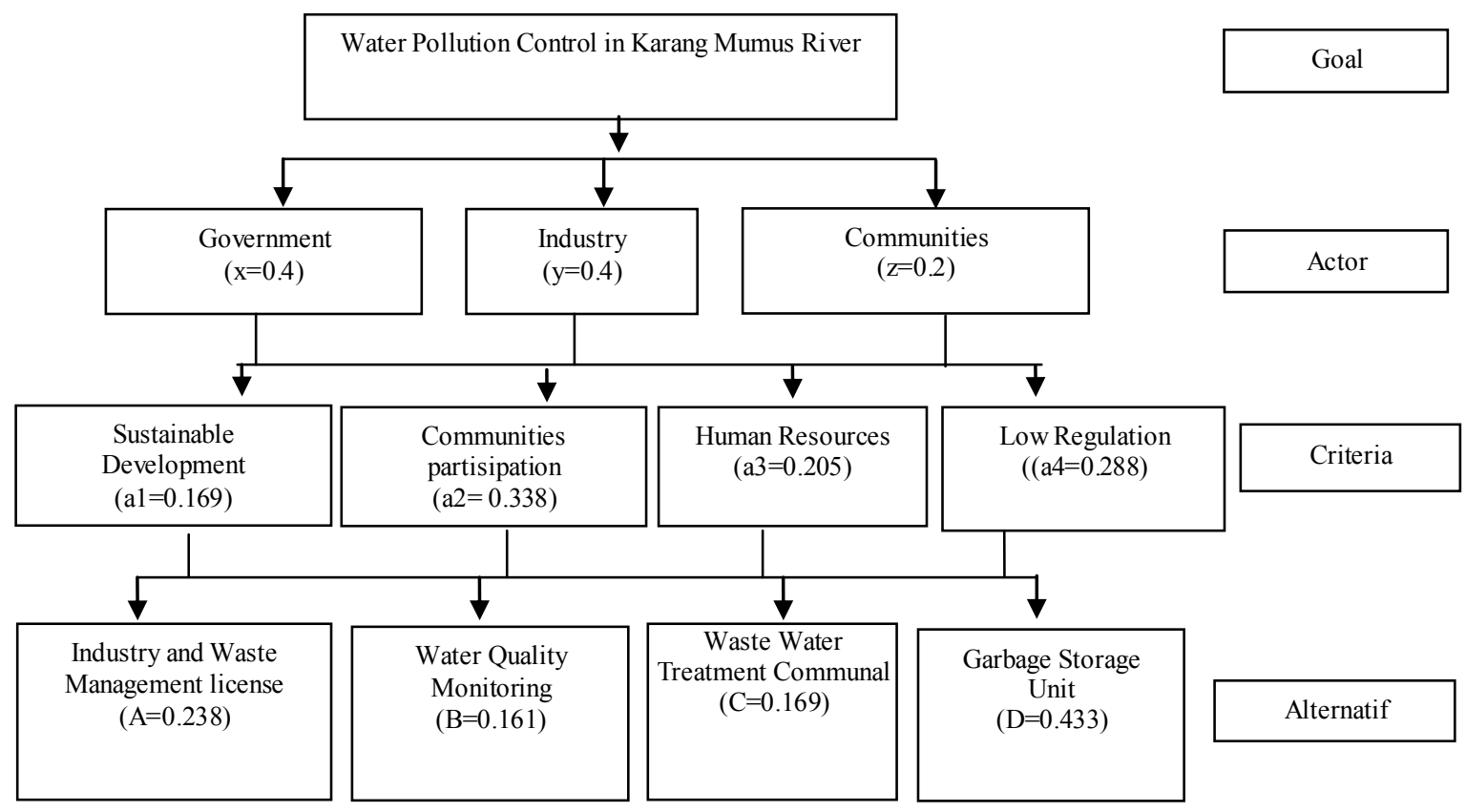

Fig. 4. Hierarchical Matrix Base on Priority

Graphic of priorities for actor contribution to pollution control, shown in Figure 5. Government and industry have same priority value. It's mean they are should be manage environment along the river. Specifically for waste water management and water quality monitoring. Cooperation inter discipline knowledge, stakeholder and government side are important things in sustainable development [7]. Three pillars sustainability development are social, economic and environmental [8].

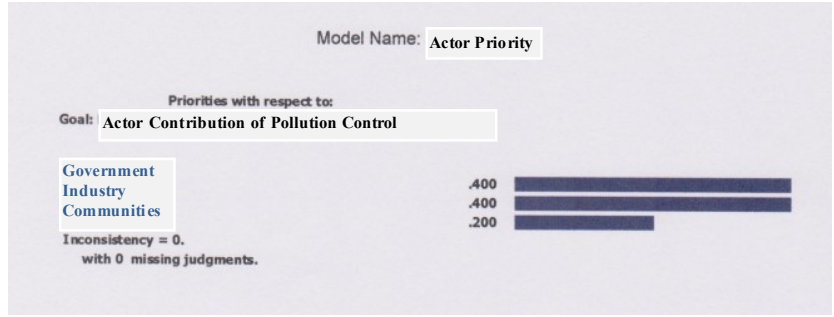

Figure 5. Priorities for Actor Contribution to Pollution Control

Graphic priorities for criteria contribution to pollution control, shown in Figure 6. Communities 
participant has highest value then low regulation. It's mean communities participation is key to solve the river water pollution control problems. Water quality in surface or ground have been deteriorated because of some importance factor as increasing population, industrialization, urbanization, etc. Then water quality in the river is depend on influence various activity along the river [9]. Urbanization along the river banks to be cause river water pollution [10]. Low regulation have powerful to manage environment pollution.

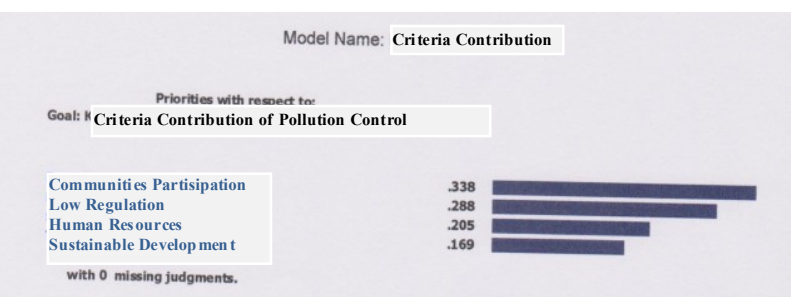

Fig. 6. Priorities for Criteria Contribution to Pollution Control

Graphic priority for alternative to river water pollution control, shown in Figure 7. Garbage storage unit have highest value than others. Human activity are produced garbage as waste. Quantity of garbage storage especially along the river banks will be impact to the garbage decrease in the river. It's depend on communities participant to keep environment. Communities along the Karang Mumus river banks said that they through garbage to the river because of nothing garbage storage near their house. Therefore needed cooperation between government, industry and communities to prepare garbage storage unit especially along the river banks.

Priority alternative of pollution control in Cibanten River, Banten, Indonesia was water quality monitoring, city spatial layout review, low regulation, stakeholder, socialisation and waste water treatment communal [7].

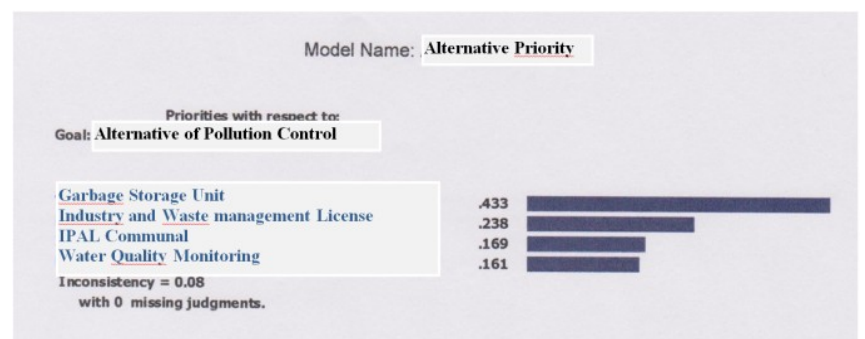

Fig. 7. Priorities for Alternative Contribution to Pollution Control

\section{Conclusion}

Government have highest priority than industry and communities to arrange river water pollution control strategy. Then communities participation is important factor to help government reach the goal. Finally alternative priority are provide garbage storage unit, industry and waste management license, waste water treatment communal and water quality monitoring.

\section{References}

1. http://e-journal.fhumnul.ac.id/index.php/beraja (in Indonesia)

2. PERDA KALTIM No. 2 Tahun 2011 tentang Pengelolaan Kualitas Air dan pengendalian Pencemaran Air (in Indonesia).

3. I. Yuliana, eJournal Sosiatri-Sosiologi, 1 (1): 20-30 (2013). http://e-journal.sos.fisip-unmul.org. (in Indonesia).

4. T.L. Saaty, Int. J. Services Sciences, Vol. 1, No. 1 (2008)

5. J. Guo, Z. Zhang, Q. Sun, China Saf Sci J 18(5):148153(2008)

6. O. Tong, S. Shuai, Z. Yun, C. Yu, L. Su, S.Z. Shu, Clean Techn. Environ. Pollicy 14: 857-868 (2012).

7. Baherem, Suprihatin, NS. Indrasti, Jurnal Pengelolaan Sumberdaya Alam dan Lingkungan Vol. 4 No.1, 6069, (Juli 2014) (in Indonesia).

8. R. Rossi, M. Gastaldi, G. Gecchele, Eur. Transp. Res. Rev, 5:11-26, (2013)

9. Effendi Hefni, 2015, Elsevier B. V, Procedia Environmental Sciences 33, 562-567, (2016)

10. S. Kalavaty, T. R. Sharma, P. Sureshkumar, 2011, Arch. Environ. Sci, 5, 55-61, (2011). 